\title{
Properties of the newly isolated extracellular thermo-alkali-stable laccase from thermophilic actinomycetes, Thermobifida fusca and its application in dye intermediates oxidation
}

\author{
Cheng-Yu Chen ${ }^{1}$, Yu-Chun Huang ${ }^{2}$, Chien-Mei Wei ${ }^{2}$, Menghsiao Meng ${ }^{1}$, Wen-Hsiung Liư ${ }^{3}$ and Chao-Hsun Yang ${ }^{2 *}$
}

\begin{abstract}
Laccases are diphenol oxidases that have numerous applications to biotechnological processes. In this study, the laccase was produced from the thermophilic actinomycetes, Thermobifida fusca BCRC 19214. After $36 \mathrm{~h}$ of fermentation in a 5-liter fermentor, the culture broth accumulated $4.96 \mathrm{U} / \mathrm{ml}$ laccase activity. The laccase was purified 4.64-fold as measured by specific activity from crude culture filtrate by ultrafiltration concentration, Q-Sepharose FF and Sephacryl TM S-200 column chromatography. The overall yield of the purified enzyme was 7.49\%. The molecular mass of purified enzyme as estimated by SDS-PAGE and by gel filtration on Sephacry TM S-200 was found to be $73.3 \mathrm{kDa}$ and $24.7 \mathrm{kDa}$, respectively, indicating that the laccase from T. fusca BCRC 19214 is a trimer. The internal amino acid sequences of the purified laccase, as determined by LC-MS/MS, had high homology with a superoxide dismutase from T. fusca YX. Approximately $95 \%$ of the original activity remained after treatment at $50^{\circ} \mathrm{C}$ for $3 \mathrm{~h}$. and approximately 75\% of the original activity remained after treatment at pH 10.0 for $24 \mathrm{~h}$. This laccase could oxidize dye intermediates, especially 2,6-dimethylphenylalanine and $p$-aminophenol, to produce coloring. This is the first report on laccase properties from thermophilic actinomycetes. These properties suggest that this newly isolated laccase has potential for specific industrial applications.
\end{abstract}

Keywords: Laccase; Dye intermediate; Thermophilic; Thermobifida fusca; LC-MS/MS

\section{Introduction}

Laccases (E.C. 1.10.3.2) are well-known enzymes that were first isolated from the lacquer tree, Rhus vernicifera. They have received increasing attention in recent decades due to their ability to oxidize both phenolic and nonphenolic lignin-related compounds and highly recalcitrant environmental pollutants, which makes them very useful for applications related to biotechnological processes (Mukhopadhyay et al., 2013; Couto and Herrera, 2006; Albino et al., 2004). Laccases are members of the multi-copper oxidase family of enzymes that contain four copper atoms in their functional units. Laccases have been isolated from many plants, fungi and bacteria. Most known laccases are of fungal origin, and

\footnotetext{
* Correspondence: chyang@pu.edu.tw

${ }^{2}$ Department of Cosmetic Science, Providence University, Taichung 43301, Taiwan

Full list of author information is available at the end of the article
}

they participate in a variety of physiological functions, such as stress defense and lignin degradation (Baldrian, 2006; Giardina et al. 2010; Kües and Rühl 2011).

One application for laccase is hair coloring. Oxidationbased hair color, which has dominated the hair color market, consists of dye intermediates and an oxidizing agent (Saito et al., 2012). In a typical hair color product, the dye intermediates are $p$-diamines and $p$-aminophenols, and hydrogen peroxide is used as the oxidant in the dyeing process. After mixing, they form chromatic indo dyes at the time of use. However, side reactions with hair proteins commonly occur simultaneously because of the severe reactions conditions, resulting in hair damage (Saito et al., 2012). The commercial hydrogen peroxide oxidative-type hair dyeing formulations are mutagenic. Some hair dyeing components become strongly mutagenic after oxidation by hydrogen peroxide (Ames et al., 1975). Laccase-based hair dyes are less irritating and easier to handle than 
current hair dyes, as laccases replaced hydrogen peroxide as the oxidizing agent in the dyeing formula (Couto and Herrera, 2006).

Streptomycetes are widespread soil actinomycetes that play important roles in the decomposition of biopolymers such as lignin, cellulose, hemicellulose, chitin, keratin and pectin (Locci, 1989). Although most laccases are found in mesophilic microorganisms, thermophilic microorganisms are considered to be good sources of thermostable and novel enzymes with potential industrial importance. However, little has been reported on laccase production by thermophilic actinomycetes. To produce enzymes for the development of enzymatic degradation of renewable lignocellulose, we isolated 70 potent extracellular lignocellulolytic enzyme-producing thermophilic actinomycetes from compost soils collected in Taiwan (Yang et al., 2009). Of the 70 strains of thermophilic actinomycetes, strain No. 10-1 had the best laccase activity. According to its biological properties and 16S rDNA similarity, this newly isolated strain was identified as Thermobifida fusca and deposited in the Bioresource Collection and Research Center (BCRC, Hsinchu, Taiwan) with stock number BCRC 19214 (Chen et al., 2013). Database mining of the complete genome sequence of T. fusca YX, which was accessible in 2007 (Lykidis et al. 2007), did not find genes that encode fungal laccase-like proteins. There are no reports on laccase production and properties by $T$. fusca before.

The coloring reactions are usually carried out at alkaline $\mathrm{pH}$ because the hair swells and the penetration of dyes is enhanced. Although many laccases have been isolated, few studies have reported laccases with high activity under neutral or alkaline conditions (Gouka et al., 2001; Heinzkill et al., 1998; Sulistyaningdyah et al., 2004). The purpose of this study was to produce thermo-alkali-stable laccase from thermophilic actinomycetes. The enzyme properties and dye intermediates oxidation application of the laccase were also investigated. The results of this investigation have implications for cosmetics and human health.

\section{Materials and methods Microorganisms}

T. fusca BCRC 19214, cultivated routinely in CYC medium (Czapek-Dox powder $33 \mathrm{~g} / \mathrm{L}$, yeast extract $2 \mathrm{~g} / \mathrm{L}$, casamino acids $6 \mathrm{~g} / \mathrm{L}, \mathrm{pH} 7.2$ ) at $50^{\circ} \mathrm{C}$, was studied in this study. This strain was deposited in the Bioresource Collection and Research Center (BCRC, Hsinchu, Taiwan) with stock number.

\section{Materials}

Sugarcane bagasse, corncob, and pine sawdust were collected from the local market and washed extensively with running water until the residual soluble sugar was removed. Then, they were dried and mixed in a blender. The resulting small pieces, passed through a 100 mesh screen, were collected and used in this study. Czapekdox powder, yeast extract, casamino acids, and agar were obtained from BD (Sparks, MD, USA). Q-Sepharose FF and Sephacryl ${ }^{\mathrm{m}} \mathrm{S}-200$ were supplied by GE Healthcare (Little Chalfont, UK). The protein assay kit and SDSPAGE molecular weight standards were obtained from Bio-Rad Laboratories (Hercules, CA, USA). Dye intermediates, inorganic salts and all other chemicals were purchased from Sigma (St. Louis, MO, USA).<smiles>Nc1ccc(N)cc1</smiles><smiles>Cc1cccc(C)c1C[C@H](N)C(=O)O</smiles>

2,6-dimethylphenylalanine<smiles>Nc1ccccc1O</smiles>

o-aminophenol

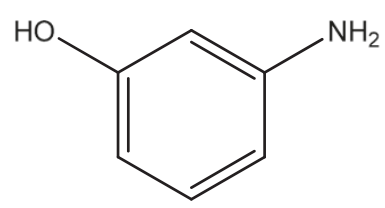

$m$-aminophenol

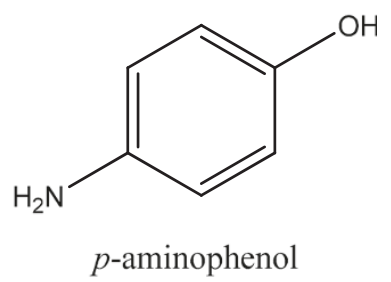

Figure 1 Chemical structure of dye intermediates. 


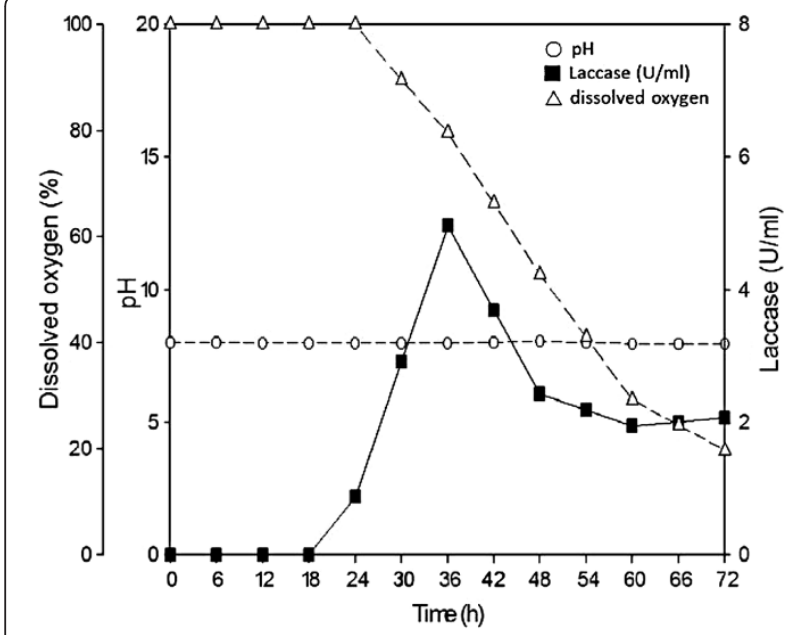

Figure 2 Time course for production of laccase in a 5 -liter fermentor by $T$. fusca BCRC 19214. The operation conditions were as follows: working volume, 3 liter; inoculum size, 1\%; agitation speed, $300 \mathrm{rpm}$; aeration rate, $1 \mathrm{vvm}$; temperature, $50^{\circ} \mathrm{C}$. Symbols: (-) laccase, $(\Delta)$ dissolved oxygen, (o) $\mathrm{pH}$.

\section{Cultivation in a fermentor}

The laccase-producing strain was cultivated in a 5-liter fermentor (Biostat B, B. Braun, Melsungen, Germany). A 500-ml Hinton flask containing $100 \mathrm{ml}$ of bagasse medium was inoculated with the strain cultured at $50^{\circ} \mathrm{C}$ and shaken $(150 \mathrm{rpm})$ for $48 \mathrm{~h}$; this was used as the seed culture. The 5-liter fermentor was loaded with 3 liters of bagasse medium. Cultivation was performed at $50^{\circ} \mathrm{C}, 1.0$ v.v.m. aeration and $300 \mathrm{rpm}$ agitation.

\section{Enzyme purification}

All purification procedures were performed at $4^{\circ} \mathrm{C}$ in $20 \mathrm{mM}$ phosphate buffer ( $\mathrm{pH}$ 8.0) unless otherwise stated. After $36 \mathrm{~h}$ cultivation of the laccase-producing strain in a 5-liter fermentor, the fermentation broth was centrifuged at $10,000 \times g$ for $30 \mathrm{~min}$ to remove the cells. The supernatant was concentrated by ultrafiltration (Pellicon XL, Biomax $10 \mathrm{~K}$, Millipore). The concentrated solution was then applied to a Q-Sepharose FF anionexchange column $(1.13 \mathrm{~cm} \times 5 \mathrm{~cm})$ that was preequilibrated with phosphate buffer. After washing with the same buffer to remove inactive protein, the enzyme was eluted with a linear gradient of the buffer containing $\mathrm{NaCl}$ from $0.0 \mathrm{M}$ to $1.0 \mathrm{M}$ (flow rate: $180 \mathrm{ml} / \mathrm{h}$ ). Enzyme activity was detected within the range $0.4 \mathrm{M}$ to $0.6 \mathrm{M}$ $\mathrm{NaCl}$. The main active fractions were applied to a Sephacryl ${ }^{\mathrm{mm}} \mathrm{S}-200$ column $(1.6 \times 90 \mathrm{~cm})$ that was previously equilibrated with $20 \mathrm{mM}$ phosphate buffer. Proteins were eluted at a flow rate of $30 \mathrm{ml} / \mathrm{h}$. The eluted enzymatically active fractions were pooled and used as the purified enzyme.

\section{Polyacrylamide gel electrophoresis}

SDS-PAGE was performed using 10\% gels to determine the molecular weight of the purified protein and the purity of each purification step. Coomassie Brilliant Blue R-250 was used for protein staining. LMW-SDS Maker (GE Healthcare, Little Chalfont, UK) was used as the standard. Native-10\% PAGE was performed according to standard SDS-PAGE procedures, but the gels did not contain SDS. The samples were not heated, and no SDS or $\beta$ mercaptoethanol was added. The electrophoresis was performed at $150 \mathrm{~V}$ for $1 \mathrm{~h}$ at $4^{\circ} \mathrm{C}$. After electrophoresis, the native-PAGE was washed in $20 \mathrm{mM}$ phosphate buffer (pH 8.0) at $4^{\circ} \mathrm{C}$ and $50 \mathrm{rpm}$ for $90 \mathrm{~min}$, with buffer changes every $30 \mathrm{~min}$. The native-PAGE was soaked in $20 \mathrm{mM}$ 2,6-DMP (dissolved in $20 \mathrm{mM}$ phosphate buffer ) and then incubated at $50^{\circ} \mathrm{C}$ until bands began to appear.

\section{Internal amino acid sequence of laccase by LC-MS/MS}

The laccase internal amino acid sequence was performed by in-gel digestion of the protein and sequencing of the different peptides by liquid chromatography tandem mass spectrometry (LC-MS/MS) using an Applied Biosystems QStar LC-MS/MS spectrometer (Life Technologies Corp., Carlsbad, USA) as described previously (Chen et al., 2013). The analysis was performed at the Biotechnology center, NCHU (National Chung Hsing University). The mass spectrometry information was analyzed using Mascot software (Matrix Science Ltd., London, UK) and the NCBInr database. The peptide mass accuracy was $\pm 0.5 \mathrm{Da}$ for Mascot analysis. The resulting amino acids were matched to the NCBI database.

\section{Laccase activity}

Unless otherwise indicated, the standard laccase activity assay was carried out at $50^{\circ} \mathrm{C}$ for $15 \mathrm{~min}$, using $20 \mathrm{mM}$ 2,6- dimethoxyphenol (2,6-DMP) as substrate in $20 \mathrm{mM}$ phosphate buffer ( $\mathrm{pH}$ 8.0). 2,6-DMP oxidation was monitored by the increase in absorbance at $470 \mathrm{~nm}$ $\left(\varepsilon 470=35645 \mathrm{M}^{-1} \mathrm{~cm}^{-1}\right)$. One unit was defined as the activity required to oxidize $1 \mathrm{nmol}$ of the substrate per minute under the indicated reaction conditions (Chen et al., 2013).

\section{Oxidative activities for dye intermediates}

The dye intermediates used in this study are shown in Figure 1 . The oxidation activities using $p$-phenylenediamine, 2,6-dimethylphenylalanine, and aminophenols were determined in a DMSO solution (final concentration was $0.5 \%)$. Oxidation was spectroscopically monitored in phosphate buffer ( $\mathrm{pH}$ 8.0). The final concentrations of the 


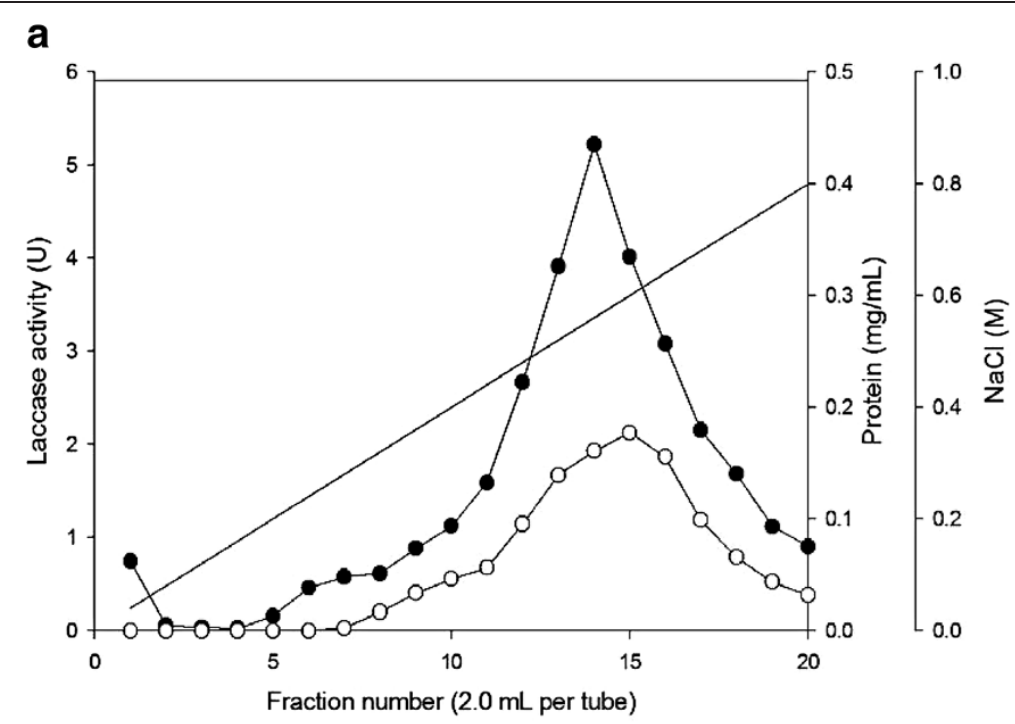

b

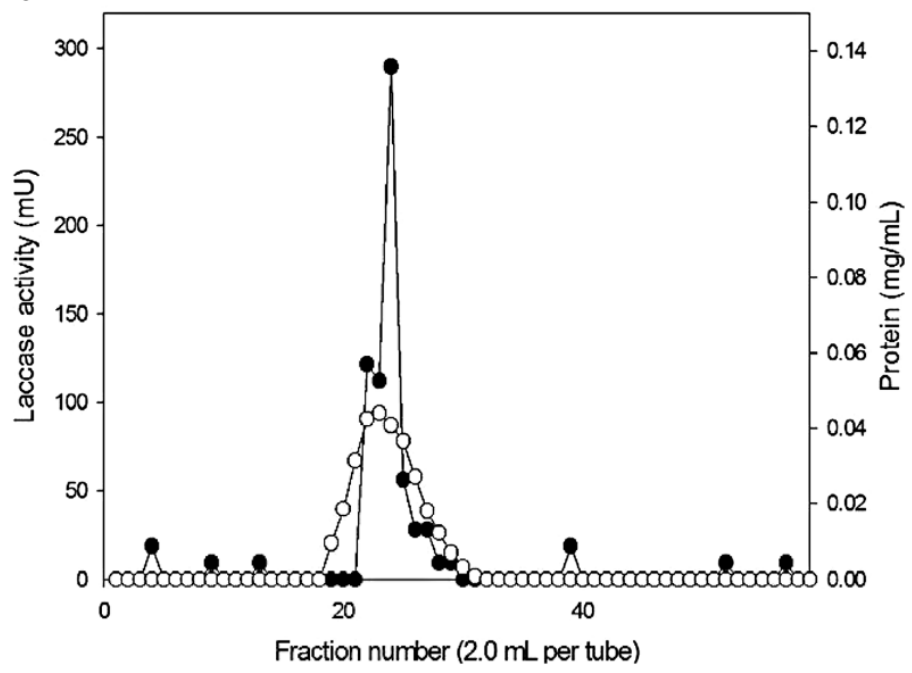

Figure 3 Purification of laccase by column chromatography. (a) Q-Sepharose FF chromatography. (•) laccase activity; (o) Protein (mg/ml); (-) $\mathrm{NaCl}$ gradient. Column: $1.13 \times 5 \mathrm{~cm}$; flow rate: $180 \mathrm{ml} / \mathrm{h}$. (b) Sephacryl ${ }^{\mathrm{TM}} \mathrm{S}-200$ chromatography. (•) laccase activity; (o) Protein (mg/ml); (-) NaCl gradient. Column: $1.6 \times 90 \mathrm{~cm}$; flow rate: $30 \mathrm{ml} / \mathrm{h}$.

substrates and the buffer were $20 \mathrm{mM}$. The oxidation was monitored at $470 \mathrm{~nm}$.

\section{Statistical analysis}

All analytic measurements were performed at least 3 times. The data are expressed as the mean $\pm \mathrm{SD}$.

\section{Results}

Production of the laccase in fermentor

Bagasse, corncob and pine sawdust were used as carbon sources to produce the laccase from $T$. fusca BCRC 19214. The highest extracellular laccase activity was observed when T. fusca BCRC 19214 was grown in a mineral medium containing bagasse as the carbon source.

Table 1 Summary of the purification of laccase from T. fusca BCRC 19214

\begin{tabular}{|c|c|c|c|c|c|c|}
\hline Step & Volume $(\mathrm{mL})$ & Total protein $(\mathrm{mg})$ & Total activity (U) & Specific activity (U/mg) & Purification (fold) & Yield (\%) \\
\hline Crude culture filtrate & 760.00 & 12.31 & 49.04 & 3.98 & 1.00 & 100.00 \\
\hline Ultrafiltration & 20.00 & 7.94 & 39.09 & 11.27 & 2.83 & 79.71 \\
\hline Q-Sepharose FF & 16.00 & 2.36 & 30.75 & 13.05 & 3.28 & 62.71 \\
\hline Sephacry|TM S-200 & 6.00 & 0.20 & 3.68 & 18.50 & 4.64 & 7.49 \\
\hline
\end{tabular}




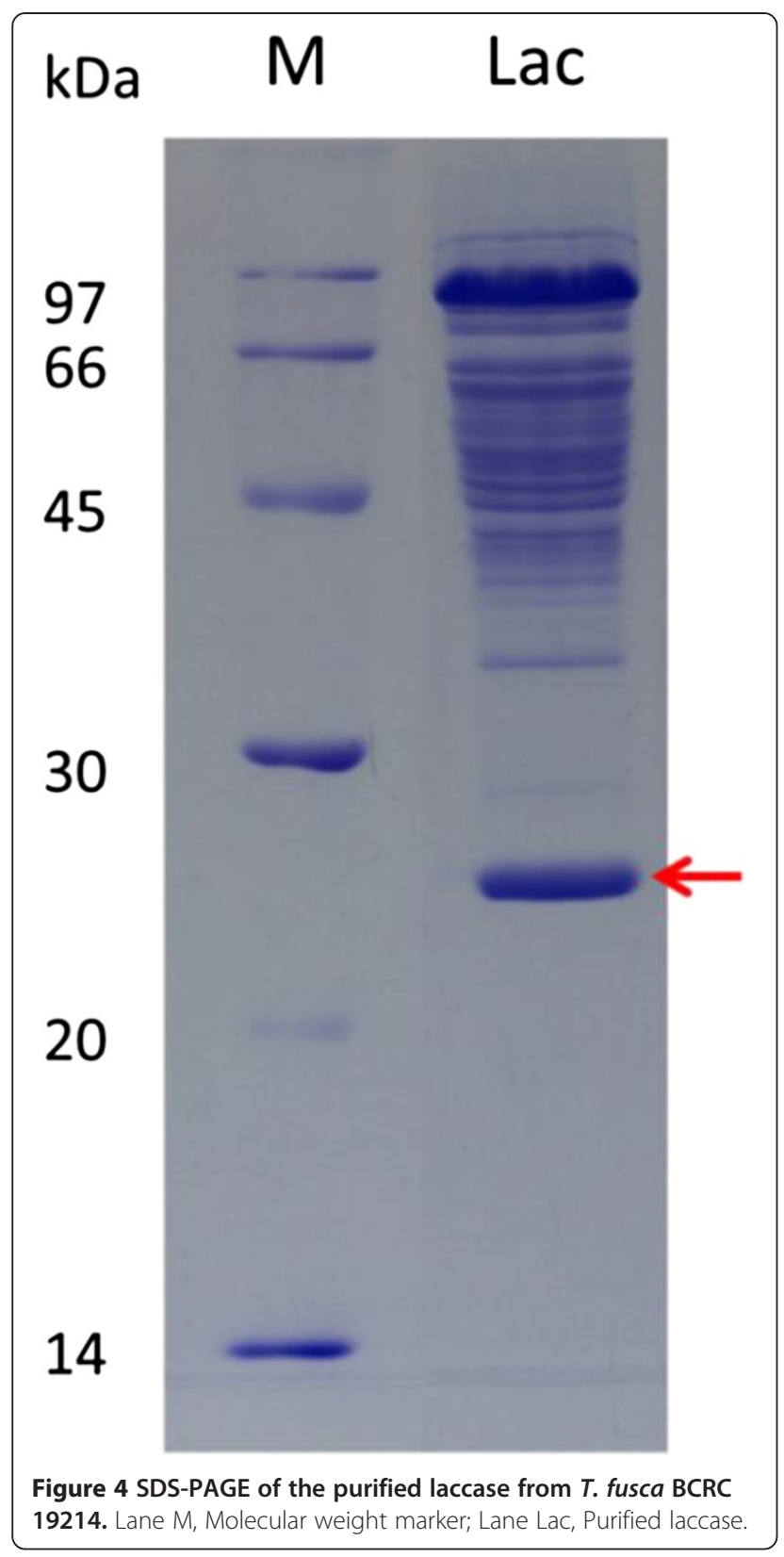

Next, the culture conditions for the production of laccase were investigated in a 5-liter fermentor. Typical enzyme levels produced by T. fusca BCRC 19214 in a 5liter fermentor are shown in Figure 2. The rapid consumption of oxygen paralleled an increase in laccase activity during the growth phase of the culture. The appearance of laccase activity in the culture broth became significant after $24 \mathrm{~h}$ of cultivation. Maximum laccase activity was approximately $4.96 \mathrm{U} / \mathrm{ml}$ in the culture broth after $36 \mathrm{~h}$ of cultivation, and the laccase activity decreased after further cultivation time.

\section{Purification of laccase from $T$. fusca BCRC19214}

The purification of laccase was performed as described in the Materials and Methods section. Gel-filtration chromatography of Q-Sepharose FF is shown in Figure 3a. The major esterase activity fraction was eluted and applied to a DEAE-Sepharose CL-6B column (Figure 3b). The enzymatically active fractions were eluted, pooled and used as the purified enzyme. The results of the total purification are summarized in Table 1. The purified enzyme obtained exhibited $7.49 \%$ of the total initial activity and there was a 4.64-fold increase in its specific activity compared with the crude culture filtrate.

\section{Properties of laccase from T. fusca BCRC19214}

As shown in Figure 4, the purified enzyme showed an apparent single protein band on SDS-PAGE (10\% gel). The subunit of the single protein band was estimated to be $24.7 \mathrm{kDa}$ from its mobility relative to those of standard proteins on SDS-PAGE. The molecular mass of the purified enzyme was estimated to be $73.3 \mathrm{kDa}$ by Sephacryl ${ }^{\mathrm{sm}}$ S-200 gel filtration, indicating that the purified enzyme is a trimer.

Activity assays were performed using 2,6-DMP as substrate to identify the $\mathrm{pH}$ and temperature properties. The optimal $\mathrm{pH}$ and temperature of the purified enzyme were 8.0 and $60^{\circ} \mathrm{C}$, respectively (Figure 5). The purified enzyme was stable over a $\mathrm{pH}$ range of $5.0-10.0$ at $4^{\circ} \mathrm{C}$ for 24 h. Approximately $95 \%$ of the original activity remained after treatment at $50^{\circ} \mathrm{C}$ for $3 \mathrm{~h}$. Approximately $75 \%$ of the original activity remained at $\mathrm{pH} 10.0$ for $24 \mathrm{~h}$.

Among the various metal salts and chemical reagents tested, it was found that the purified enzyme activity was partially inhibited by $1 \mathrm{mM} \mathrm{Hg}^{2+}$ (Table 2). The presence of $\beta$-mercaptoethanol and EDTA significantly reduced the enzyme activity. The enzyme activity partially inhibited by sodium dodecyl sulfate (SDS) and sodium azide (Table 3). The effects of organic solvent on the activity of purified laccase were given in Table 4 . With $20 \%$ water miscible solvent like methanol, ethanol, isopropanol, aceton, and dimethyl sufoxide (DMSO) in the reaction system, the activity dropped to $20-74 \%$. Acetonitrile and dimethylformamide (DMF) increased the activities to $110-118 \%$.

Internal amino acid sequence of the laccase by LC-MS/MS The internal sequences of the purified laccase were determined by digestion with trypsin and sequence analysis using LC-MS/MS. Three sequences (GANDALEQLA EAR, AHFSAAATGIQGSGWAILAWDILGQR, and AF WNVVNWADVAK) were detected. Comparisons were then made to all protein sequence in the NCBI database. The results of a BLAST search indicated that the internal sequences had high homology with a superoxide dismutase 


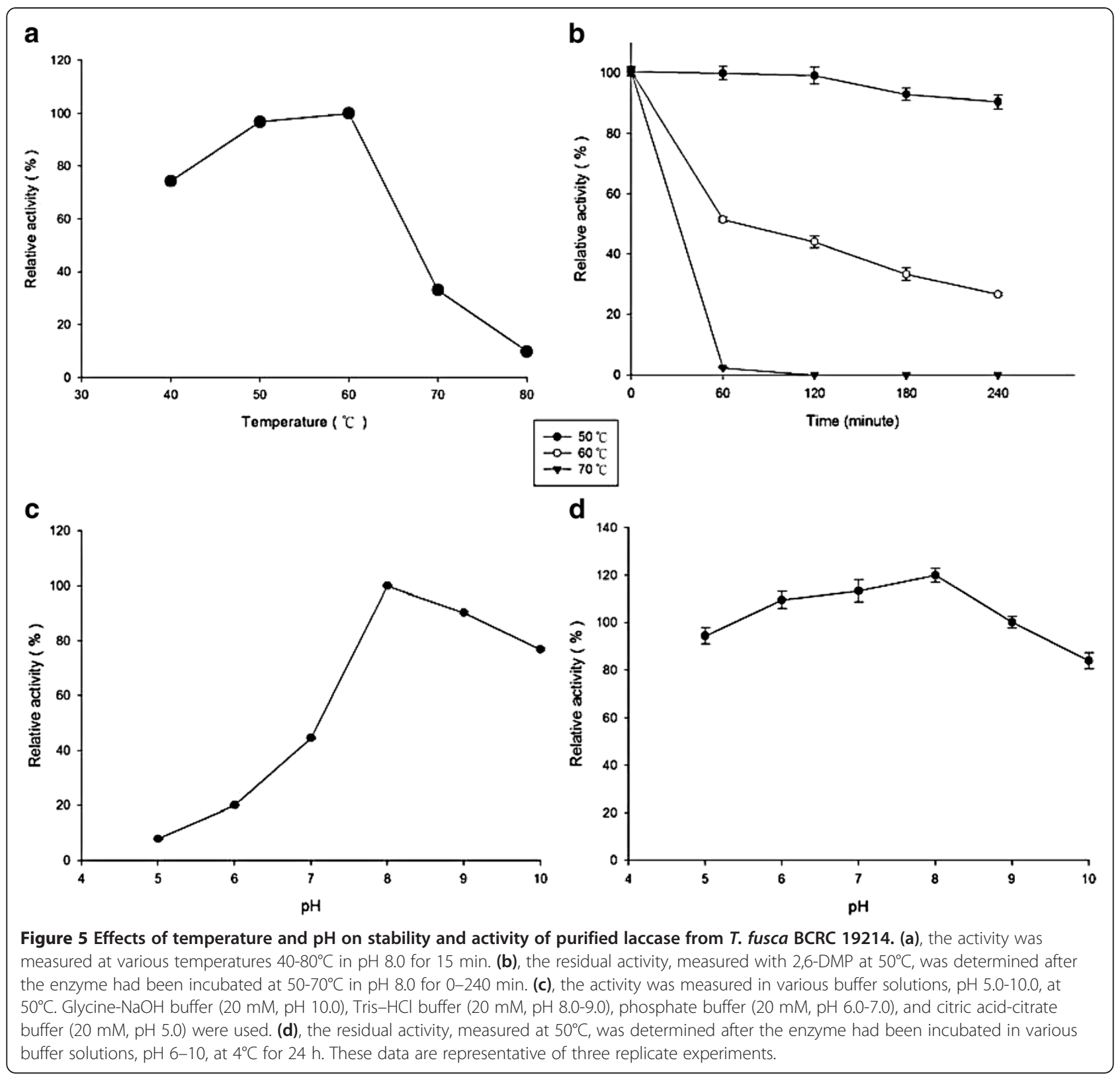

(SOD) proteins product from T. fusca YX (Accession number 289018.1). We named the protein as Tfu-lac.

\section{Dye oxidation properties}

As shown in Table 5, the laccase showed oxidation activity for 5 dye intermediates, including $p$-phenylenediamine, 2,6-dimezthylphenylalanine, $o$-aminophenol, $p$-aminophenol and $m$-aminophenol at $\mathrm{pH}$ 8.0. The chromogenic reactions of laccase for the dye oxidation widely used in hair color are shown in Figure 6. The laccase exhibited the higher activities toward 2,6-dimethylphenylalanine and $p$-aminophenol. In contrast, the oxidation effect of laccase was less for $m$-aminophenol.

\section{Discussion}

Thermophilic actinomycetes are of particular interest because they produce a variety of thermostable enzymes that are involved in the degradation process (Tuncer and Ball, 2002; Yang and Liu, 2004; Yang et al., 2007; Yang and Liu, 2008; Yang et al., 2010; Huang et al. 2010; Huang et al., 2011). T. fusca seems to be unique among thermophilic actinomycetes in having a laccase.

Some laccases had been isolated from microorganisms and the properties were summarized in Table 6. Compared with other laccases, the optimum temperature and optimum $\mathrm{pH}$ varied from $40^{\circ} \mathrm{C}$ to $85^{\circ} \mathrm{C}$ and 3.0 to 9.0 , respectively. The laccases from Bacillus subtilis and 
Table 2 Effect of metal salts on the activity of laccase from T. fusca BCRC 19214

\begin{tabular}{cc}
\hline Metal salt (1 $\mathbf{~ m M})$ & Relative activity* (\%) \\
\hline $\mathrm{None}$ & 100 \\
$\mathrm{ZnCl}_{2}$ & $97 \pm 4$ \\
$\mathrm{HgCl}_{2}$ & $86 \pm 6$ \\
$\mathrm{CaCl}_{2}$ & $102 \pm 2$ \\
$\mathrm{FeCl}_{2}$ & $97 \pm 4$ \\
$\mathrm{MnCl}_{2}$ & $96 \pm 3$ \\
$\mathrm{MgCl}_{2}$ & $98 \pm 4$ \\
$\mathrm{NaCl}$ & $98 \pm 6$ \\
$\mathrm{KCl}$ & $98 \pm 3$ \\
$\mathrm{CoSO}_{4}$ & $97 \pm 4$ \\
$\mathrm{CuSO}_{4}$ & $102 \pm 5$ \\
\hline
\end{tabular}

* The relative activity was measured at $50^{\circ} \mathrm{C}$ for $15 \mathrm{~min}$, using $20 \mathrm{mM}$ 4- dimethoxybenzylalcohol (veratryl alcohol) as the substrate in $20 \mathrm{mM}$ phosphate buffer ( $\mathrm{pH}$ 8.0).

Pseudomonas aerophilum had the highest optimal temperature. However, the optimal $\mathrm{pH}$ of these two enzymes retained in neutral to acidic (Martins et al., 2002; Fernandes et al., 2010). The laccase from Streptomyces sviceus had the wild $\mathrm{pH}$ range (5.0-11.0). Approximately $50 \%$ of the original activity remained after treatment at $50^{\circ} \mathrm{C}$ for $226 \mathrm{~min}$. (Gunne and Urlacher, 2012). The laccase purified from T. fusca BCRC 19214 had the similar wild $\mathrm{pH}$ range with the property from $S$. sviceus. The thermostability of the laccase from T. fusca BCRC 19214 was better than the laccase from S. sviceus. Therefore, the laccase purified from T. fusca BCRC 19214 was an

Table 3 Effect of inhibitors on the activity of laccase from T. fusca BCRC 19214

\begin{tabular}{ccc}
\hline Inhibitor & Concentration (mM) & Relative activity* (\%) \\
\hline None & - & 100 \\
SDS & 0.1 & $94 \pm 3$ \\
& 1 & $73 \pm 3$ \\
sodium azide & 10 & $63 \pm 6$ \\
& 0.1 & $87 \pm 2$ \\
--mercaptoethanol & 1 & $84 \pm 4$ \\
& 10 & $80 \pm 3$ \\
EDTA & 0.1 & $86 \pm 3$ \\
& 1 & $4 \pm 2$ \\
& 10 & $0 \pm 1$ \\
& 0.1 & $24 \pm 2$ \\
& 1 & $23 \pm 2$ \\
& 10 & $5 \pm 1$
\end{tabular}

* The relative activity was measured at $50^{\circ} \mathrm{C}$ for $15 \mathrm{~min}$, using $20 \mathrm{mM} \mathrm{2,6-}$ dimethoxyphenol (2,6-DMP) as the substrate in $20 \mathrm{mM}$ phosphate buffer ( $\mathrm{pH}$ 8.0). SDS, Sodium dodecyl sulfate; EDTA, Ethylenediaminetetraacetic acid.
Table 4 Effect of organic solvents on the activity of laccase from $T$. fusca BCRC 19214

\begin{tabular}{ccc}
\hline Organic compounds & Concentration $(\%, \mathbf{v} / \mathbf{v})$ & Relative activity* $(\%)$ \\
\hline None & - & 100 \\
Methanol & 10 & $59 \pm 3$ \\
Ethanol & 20 & $34 \pm 3$ \\
Isopropanol & 10 & $66 \pm 3$ \\
& 20 & $40 \pm 4$ \\
Acetone & 10 & $61 \pm 2$ \\
& 20 & $36 \pm 4$ \\
Dimethyl sulfoxide & 10 & $50 \pm 2$ \\
(DMSO) & 20 & $20 \pm 1$ \\
Acetonitrile & 10 & $101 \pm 1$ \\
& 20 & $74 \pm 4$ \\
Dimethylformamide & 10 & $160 \pm 6$ \\
(DMF) & 20 & $118 \pm 5$ \\
\hline
\end{tabular}

* The relative activity was measured at $50^{\circ} \mathrm{C}$ for $15 \mathrm{~min}$, using $20 \mathrm{mM} \mathrm{2,6-}$ dimethoxyphenol (2,6-DMP) as the substrate in $20 \mathrm{mM}$ phosphate buffer ( $\mathrm{pH}$ 8.0).

excellent thermo-alkali-stable laccase for hair coloring and further industrial applications.

Addition of $10 \mathrm{mM}$ SDS lead to a reduction of laccase activity to $63 \%$. Addition of $10 \mathrm{mM}$ sodium azide, a well-known laccase inhibitor, led to a decrease of activity by $20 \%$, whereas many laccases are completely inhibited by concentrations in the micromolar range (Gunne and Urlacher, 2012). The relative stability of the laccase from T. fusca BCRC 19214 with chemicals allows use of the enzyme in a wide variety of reaction compositions.

The laccse activity was reduced by metal ions of $\mathrm{Hg}$. It was similar with the results from Strpeomyces psammoticus (Niladevi et al., 2008), Trametes hirsute (Couto and Herrera, 2006), and Paraconiothyrium variabile (Forootanfar et al., 2011). The role of copper in the enhancement of laccase activity has been well

Table 5 Oxidation activities of laccase from T. fusca BCRC 19214 for dye intermediates

\begin{tabular}{lrrrr}
\hline Substrate & \multicolumn{4}{c}{ Relative activity (\%) } \\
\cline { 2 - 5 } & Tfu & Flac1 $^{*}$ & BOD $^{*}$ & RvL $^{*}$ \\
\hline p-phenylenediamine & 47.3 & 800.0 & 29.4 & 47.4 \\
o-aminophenol & 71.6 & $\mathbf{2 , 9 0 0 . 0}$ & $\mathbf{5 4 7 . 0}$ & $\mathbf{2 7 4 . 7}$ \\
2,6-dimethylphenylalanine & $\mathbf{1 0 0 . 0}$ & 100.0 & 100.0 & 100.0 \\
p-aminophenol & 96.0 & 100.0 & 11.7 & 9.0 \\
m-aminophenol & 0.4 & - & - & -
\end{tabular}

*Data from Saito et al., 2012. 


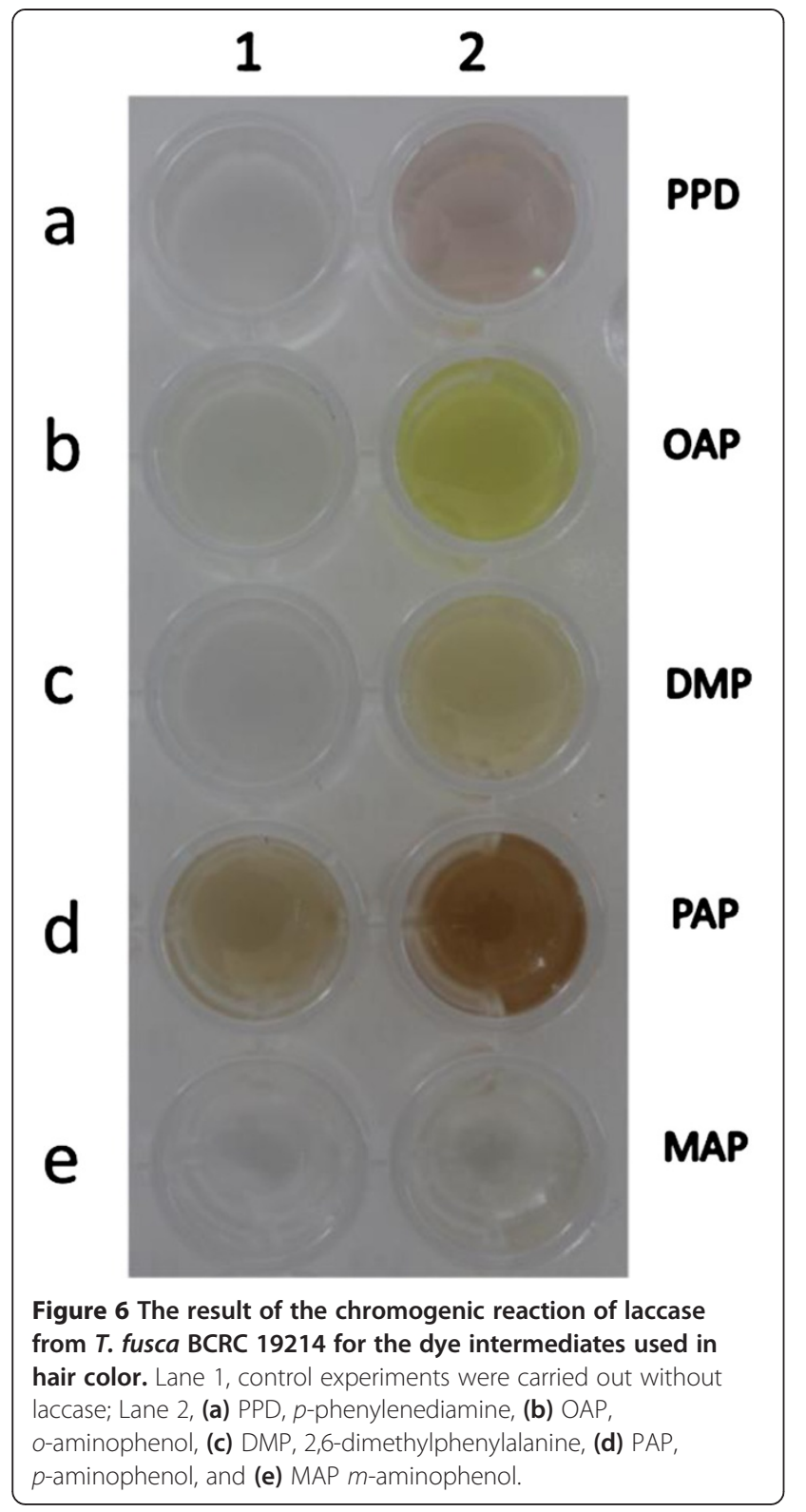

demonstrated in both fungi and bacteria (Givaudan et al., 1993). Similar result has been reported from Streptomyces cyaneus (Arias et al., 2003). However, the present result on the effect of $\mathrm{Cu}$ on the purified laccase was no enhancement effects.

With 20\% water miscible solvent like acetonitrile and DMF in the reaction system, the laccase increased the activities to $110-118 \%$. They were suggested to weaken the hydrophobic interaction and increased the stability of laccase in aqueous solutions (Kovrigin and Potekhin, 2000). With 40\% solvent like DMSO, methanol, 2propanol, acetonitrile, and aceton, the laccase activity from Streptomyces sviceus dropped to 20-40\% (Gunne
Table 6 Biochemical properties of some purified laccase

\begin{tabular}{|c|c|c|c|c|}
\hline Source & $\begin{array}{c}\text { Optimum } \\
\text { temperature }\end{array}$ & $\begin{array}{c}\text { Optimum } \\
\text { pH }\end{array}$ & $\begin{array}{c}\text { MW } \\
(\mathrm{kDa})\end{array}$ & Reference \\
\hline $\begin{array}{l}\text { Trametes } \\
\text { versicolor }\end{array}$ & 40 & $4.0-5.0$ & 66 & $\begin{array}{l}\text { Minussi et al., } \\
2007\end{array}$ \\
\hline $\begin{array}{l}\text { Ganoderma } \\
\text { lucidum }\end{array}$ & 60 & 3 & 68 & $\begin{array}{l}\text { Ding et al., } \\
2012\end{array}$ \\
\hline Botrytis cinerea & 60 & 3.5 & 74 & $\begin{array}{l}\text { Slomczynski } \\
\text { et al., } 1995\end{array}$ \\
\hline $\begin{array}{l}\text { Chaetomium } \\
\text { thermophile }\end{array}$ & 60 & 6 & 77 & $\begin{array}{l}\text { Chefetz et al., } \\
1998\end{array}$ \\
\hline $\begin{array}{l}\text { Cladosporium } \\
\text { cladosporioides }\end{array}$ & 50 & 3.5 & 75.17 & $\begin{array}{l}\text { Vijaykumar } \\
\text { et al., } 2011\end{array}$ \\
\hline $\begin{array}{l}\text { Schyzophylum } \\
\text { commune }\end{array}$ & 40 & 6 & 63 & $\begin{array}{l}\text { Irshad et al., } \\
2011\end{array}$ \\
\hline $\begin{array}{l}\text { Pycnoporus } \\
\text { cinnabarinus }\end{array}$ & - & 4 & 81 & $\begin{array}{l}\text { Eggert et al., } \\
1996\end{array}$ \\
\hline $\begin{array}{l}\text { Flammulina } \\
\text { velutipes }\end{array}$ & - & 5 & 28 & $\begin{array}{l}\text { Saito et al., } \\
2012\end{array}$ \\
\hline Bacillus subtilis & 85 & 4.2 & 65 & $\begin{array}{l}\text { Martins et al., } \\
2002\end{array}$ \\
\hline $\begin{array}{l}\text { Pseudomonas } \\
\text { aerophilum }\end{array}$ & 85 & 3 & 49.6 & $\begin{array}{l}\text { Fernandes } \\
\text { et al., } 2010\end{array}$ \\
\hline $\begin{array}{l}\text { Streptomyces } \\
\text { sviceus }\end{array}$ & - & 9 & 32.5 & $\begin{array}{l}\text { Gunne and } \\
\text { Urlacher } 2012\end{array}$ \\
\hline $\begin{array}{l}\text { Streptomyces } \\
\text { psammoticus }\end{array}$ & 45 & 8.5 & 43 & $\begin{array}{l}\text { Niladevi et al., } \\
2008\end{array}$ \\
\hline $\begin{array}{l}\text { Paraconiothyrium } \\
\text { variabile }\end{array}$ & 50 & 4.8 & 84 & $\begin{array}{l}\text { Forootanfar } \\
\text { et al., } 2011\end{array}$ \\
\hline
\end{tabular}

and Urlacher, 2012). The effects of organic solvent on tha activity of purified laccase from $T$. fusca BCRC 19214 were similar with the results from S. sviceus.

This enzyme differed from the sequence of the laccase-like $24.7-\mathrm{kDa}$ copper-containing oxidase Tfu1114 (Genebank number AAZ55152.1) secreted from T. fusca (Chen et al., 2013). The results of a BLAST search also indicated that the deduced amino acid sequence of the Tfu-lac protein had higher homologies with five superoxide dismutase (SOD) proteins (YP_007685998.1, YP_062104.1, YP_006642575.1, YP_003678569.1, YP_001625417.1).

Saito et al. investigated the oxidation activities of laccase Flac1 from Flammulina velutipes (Saito et al., 2012), bilirubin oxidase (BOD) from Myrothecium verrucaria (Guo et al., 1991), and laccase (RvL) from Rhus vernicifera (Sulistyaningdyah et al., 2004). All of these enzymes showed the highest activity toward $o$ aminophenol, which differ from the laccase in this study. The laccase from $T$. fusca displayed better activity toward 2,6-dimethylphenylalanine and p-aminophenol. This property could be used for developing new dye colors from the intermediates oxidation process. 


\section{Competing interests}

The authors declare that they have no competing interests.

\section{Acknowledgements}

We gratefully acknowledge financial support from the National Science Council of the Republic of China (NSC101-2313-B-126-003-MY3).

\section{Author details}

'Graduate Institute of Biotechnology, National Chung Hsing University, Taichung 40227, Taiwan. ${ }^{2}$ Department of Cosmetic Science, Providence University, Taichung 43301, Taiwan. ${ }^{3}$ Department of Biochemical Science \& Technology, National Taiwan University, Taipei 10617, Taiwan.

\section{Received: 29 June 2013 Accepted: 24 August 2013}

Published: 28 August 2013

\section{References}

Albino A, Dias AA, Bezerra RM, Pereira AN (2004) Activity and elution profile of laccase during biological decolorization and dephenolization of olive mill wastewater. Bioresour Technol 92:7-13

Ames BN, Kammen HO, Yamasaki E (1975) Dyes are mutagenic: identification of a variety of mutagenic ingredients. Proc Nat Acad Sci 72:2423-2427

Arias ME, Arenas M, Rodriguez J, Solveri J, Ball AS, Hernandez M (2003) Kraft pulp biobleaching and mediated oxidation of a non-phenolic substrate by laccase from Streptomyces cyaneus CECT3335. Appl Environ Microbiol 69:1953-1958

Baldrian P (2006) Fungal laccases - occurrence and properties. FEMS Microbiol Rev 30:215-242

Chefetz B, Chen Y, Hadar Y (1998) Purification and characterization of laccase from Chaetomium thermophilium and its role in humification. Appl Environ Microbiol 64:3175-3179

Chen CY, Hsieh ZS, Cheepudom J, Yang CH, Meng M (2013) A 24.7-kDa coppercontaining oxidase, secreted by Thermobifida fusca, significantly increasing the xylanase/cellulase-catalyzed hydrolysis of sugarcane bagasse. Appl Microbiol Biotechnol. doi:10.1007/s00253-013-4727-y

Couto SR, Herrera JLT (2006) Industrial and biotechnological applications of laccases: A review. Biotechnol Adv 24:500-513

Ding Z, Peng L, Chen Y, Zhang L, Gu Z, Shi G, Zhang K (2012) Production and characterization of thermostable laccase from the mushroom, Ganoderma lucidum, using submerged fermentation. Afr J Microbiol Res 6:1147-1157

Eggert C, Temp U, Eriksson KEL (1996) The ligninolytic system of the white rot fungus Pycnoporus cinnabarinus: purification and characterization of the laccase. Appl Environ Microbiol 62:1151-1158

Fernandes AT, Damas JM, Todorovic S, Huber R, Baratto MC, Pogni R, Soares CM, Martins LO (2010) The multicopper oxidase from the archaeon Pyrobaculum aerophilum shows nitrous oxide reductase Activity. FEBS J 277:3176-3189

Forootanfar H, Faramarzi MA, Shahverdi AR, Yazdi MT (2011) Purification and biochemical characterization of extracellular laccase from the ascomycete Paraconiothyrium variabile. Bioresour Technol 102:1808-1814

Giardina P, Faraco V, Pezzella C, Piscitelli A, Vanhulle S, Sannia G (2010) Laccases: a never-ending story. Cell Mol Life Sci 67:369-385

Givaudan A, Effose A, Faure D, Potier P, Bouillant ML, Bally R (1993) Polyphenol oxidase from Azospirillum lipoferum isolated from rice rhizosphere: evidence for laccase activity in non-motile strains of Azospirillum lipoferum. FEMS Microbiol Lett 108:205-210

Gouka RJ, van der Heiden M, Swarthoff T, Verrips CT (2001) Cloning of a phenol oxidase gene from Acremonium murorum and its expression in Aspergillus awamori. Appl Environ Microbiol 67:2610-2616

Gunne M, Urlacher VB (2012) Characterization of the alkaline laccase Ssl1 from Streptomyces sviceus with unusual properties discovered by genome mining PLoS One 7:1-8

Guo J, Liang XX, Mo PS, Li GX (1991) Purification and properties of bilirubin oxidase from Myrothecium verrucaria. Appl Biochem Biotechnol 31:135-143

Heinzkill M, Bech L, Halkier T, Schneider P, Anke T (1998) Characterization of laccases and peroxidases from wood-rotting fungi (family Coprinaceae). Appl. Environ Microbiol 64:1601-1606

Huang YC, Chen GH, Chen YF, Chen WL, Yang CH (2010) Heterologous expression of thermostable acetylxylan esterase gene from Thermobifida fusca and its synergistic action with xylanase for the production of xylooligosaccharides. Biochem Biophys Res Commun 400:718-723

Huang YC, Chen YF, Chen CY, Chen WL, Ciou YP, Liu WH, Yang CH (2011) Production of ferulic acid from lignocellulolytic agricultural biomass by
Thermobifida fusca thermostable esterase produced in Yarrowia lipolytica transformant. Bioresour Technol 102:8117-8122

Irshad M, Asgher M, Sheikh MA, Nawaz H (2011) Purification and characterization of laccase produced by Schyzophylum commune IBL-06 IN solid state culture of banana stalks. BioResources 6:2861-2873

Kovrigin EL, Potekhin SA (2000) On the stabilizing action of protein denaturants: acetonitrile effect on stability of lysozyme in aqueous solutions. Biophys Chem 83:45-59

Kües U, Rühl M (2011) Multiple multi-copper oxidase gene families in basidiomycetes - what for? Curr Genom 12:72-94

Locci R (1989) Streptomycetes and related genera. In: Williams ST, Sharpe E, Holt JG (eds) Bergey's manual of systematic bacteriology, vol 4. Williams and Wilkins, Baltimore, pp 2451-2508

Lykidis A, Mavromatis K, Ivanova N, Anderson I, Land M, DiBartolo G, Martinez M, Lapidus A, Lucas S, Copeland A, Richardson P, Wilson DB, Kyrpides N (2007) Genome sequence and analysis of the soil cellulolytic actinomycete Thermobifida fusca YX. J Bacteriol 189:2477-2486

Martins LO, Soares CM, Pereira MM, Teixeira M, Costa T, Jones GH, Henriques AO (2002) Molecular and biochemical characterization of a highly stable bacterial laccase that occurs as a structural component of the Bacillus subtilis endospore coat. J Biol Chem 277:18849-18859

Minussi RC, Miranda MA, Silva JA, Ferreira CV, Aoyama H, Marangoni S, Rotilio D, Pastore GM, Durán N (2007) Purification, characterization and application of laccase from Trametes versicolor for colour and phenolic removal of olive mill wastewater in the presence of 1-hydroxybenzotriazole. Afr J Biotechnol 6:1248-1254

Mukhopadhyay A, Dasgupta AK, Chakrabarti K (2013) Thermostability, pH stability and dye degrading activity of a bacterial laccase are enhanced in the presence of $\mathrm{Cu}_{2} \mathrm{O}$ nanoparticles. Bioresour Technol 127:25-36

Niladevi KN, Jacob N, Prema P (2008) Evidence for a halotolerant-alkaline laccase in Streptomyces psammoticus: purification and characterization. Process Biochem 43:654-660

Saito K, Ikeda R, Endo K, Tsujino Y, Takagi M, Tamiya E (2012) Isolation of a novel alkaline-induced laccase from Flammulina velutipes and its application for hair coloring. J Biosci Bioeng 113:575-579

Slomczynski D, Nakas JP, Tanenbaum SW (1995) Production and characterization of laccase from Botrytis cinerea 61-34. Appl Environ Microbiol 61:907-912

Sulistyaningdyah WT, Ogawa J, Tanaka H, Maeda C, Shimizu S (2004) Characterization of alkaliphilic laccase activity in the culture supernatant of Myrothecium verrucaria 24G-4 in comparison with bilirubin oxidase. FEMS Microbiol Lett 230:209-214

Tuncer M, Ball AS (2002) Degradation of lignocellulose by extracellular lignocellulolytic enzyme produced by Thermomonospora fusca BD25. Appl Microbiol Biotechnol 58:608-611

Vijaykumar M, Halaburgi VM, Sharma S, Sinha M, Singh TP, Karegoudar TB (2011) Purification and characterization of a thermostable laccase from the ascomycetes Cladosporium cladosporioides and its applications. Process Biochem 46:1146-1152

Yang CH, Huang YC, Chen CY (2009) Degradation of rutin by Thermoactinomyces vulgaris and other thermophilic compost isolates. J Agric Food Chem 57:5095-5099

Yang CH, Huang YC, Chen CY, Wen CY (2010) Heterologous expression of Thermobifida fusca thermostable a-amylase in Yarrowia lipolytica and its application in boiling stable resistant sago starch preparation. J Ind Microbiol Biot 37:953-960

Yang CH, Liu WH (2004) Purification and properties of a maltotruose-producing a-amylase from Thermobifida fusca. Enzyme Microb Technol 35:254-260

Yang CH, Liu WH (2008) Purification and properties of an acetylxylan esterase from Thermobifida fusca. Enzyme Microb Technol 42:181-186

Yang CH, Yang SF, Liu WH (2007) Production of xylooligosaccharides from xylans by extracellular xylanases from Thermobifida fusca. J Agric Food Chem 55:3955-3959

doi:10.1186/2191-0855-3-49

Cite this article as: Chen et al:: Properties of the newly isolated extracellular thermo-alkali-stable laccase from thermophilic actinomycetes, Thermobifida fusca and its application in dye intermediates oxidation. AMB Express 2013 3:49. 